e-ISSN: 2721-3013, p-ISSN: 2721-3005

DOI: https://doi.org/10.38035/jafm.v1i4

Received: 4 Agust 2020, Revised: 19 Agust 2020, Publish: 7 September 2020 https://creativecommons.org/licenses/by/4.0/

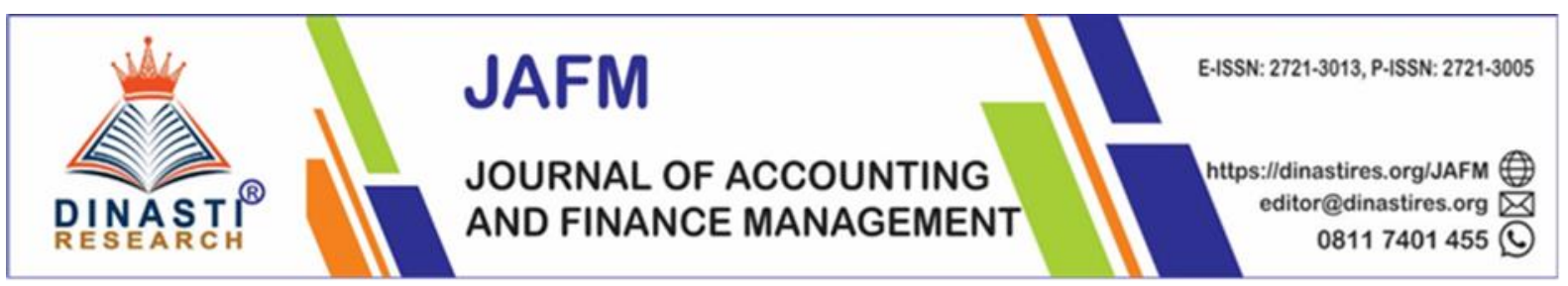

\title{
The Effect of Governance Quality and Earning Management With Internal Control as Moderating Variable Towards Firm Value
}

\author{
Mufidah $^{1 *}$, Ira Febrianti ${ }^{2}$, Masnun $^{3}$ \\ 1) Lecture of Universitas Batanghari, Jambi, Indonesia, mufidahjufri@gmail.com \\ ${ }^{2)}$ Lecture of Universitas Batanghari, Jambi, Indonesia, irraluna@gmail.com \\ ${ }^{3)}$ Lecture of Universitas Batanghari, Jambi, Indonesia, masnunthojib@gmail.com \\ *Corresponding Author: Mufidah ${ }^{1}$
}

\begin{abstract}
The purpose of this study is to analyze the influence of the quality of corporate governance, real earnings management on firm value and to analyze the influence of the quality of corporate governance with the internal control system as a moderating variable on firm value in companies included in the LQ 45 index 2016-2018. The data in this study used descriptive statistical analysis and inferential statistical analysis. The results showed that the Quality of Governance had no significant effect on Firm Value, Earnings Management had a significant effect on Firm Value and Internal Control could not moderate the effect of Governance Quality on Firm Value.
\end{abstract}

Keywords: Corporate Governance, Earning Management, Internal Control, Firm Value

\section{INTRODUCTION}

The failure of large scale companies, financial scandals, and the crisis that hit various countries has increased the discourse and demands on corporate governance that have been less attention is increasing attention. Weak independent oversight and too much executive power are the causes of the downfall of a company. In Indonesia, the issue of corporate governance emerged after a prolonged crisis since 1998 as a result of the Asian financial crisis in 1997. Since then, the government and investors have paid more attention to corporate governance practices. These events have made to realize its importance. roles and implementation of good corporate governance. Misuse of earnings management also occurs in international companies. An example is Lucent Technology, which in the November 2000 financial statements was proven to have practiced earning management which was recognized by the Securities and Exchange Commission (SEC) and had to return \$125 million in sales that were found to be incorrectly documented or fabricated.

The agency theory by Jensen and Meckling (1976) explains that the agency relationship is a contract in which one or more people (Principal) involve other parties (agents) to act on 
behalf of the owner in carrying out the company's business activities. In teori's management agency is always trying to maximize fung of the utility. Given Manajemen has freedom to choosing one accounting policies then it seems natural then came the idea that the management will choose the accounting method will specifically help to Manage in achieving objectives. (Fama \& Jensen, 1983) .

Agency theory provides the view that fraudulent practices committed by agents so that the impact on the decline in company value can be minimized by the presence of a monitoring or monitoring mechanism, namely through the implementation of corporate governance. It is hoped that the implementation of corporate governance will become an obstacle to actual behavior. In addition, it is also expected to create a more transparent, accountable, responsible, and fair organizational performance so as to increase company value.

The existence of an independent commissioner is regulated in BAPEPAM regulation No: KEP-315/BEJ/06-2000 which is enhanced by a decree No: KEP-339/BEJ/07-2001 which states that every public company must form an independent commissioner whose members are at least $30 \%$ of the total number of members of the board of commissioners. A board consisting of a large independent board of commissioners has strong control over managerial decisions.

One of the company's performance as measured by firm value. In this research ,firm Value is measured by Tobin's Q. This is a more accurate measure because it provides an overview not only of fundamental aspects, but also the extent to which the market values the company from various aspects seen by outsiders, including investors. The greater the Tobin's $Q$ value indicates that the company has good growth prospects.

The internal control system as a moderating variable can weaken the positive influence of the company's life cycle on management accrual earnings, this provides evidence that the internal control structure can be a company tool to control opportunity management behavior in all life cycle conditions, therefore it is important for companies to enforce the implementation of the structure. internal control is in accordance with the needs of the company and confirms auditors to perform auditing standards appropriately regarding the inspection of the internal control system as a basis for determining the nature, timing and extent of audit testing (Hastuti et al., 2017).

The purpose of this paper is to analyze the influence quality corporate governance and real earning management with internal control as moderating variable towards firm value.

\section{LITERATURE REVIEW}

\section{Firm Value}

Tobin's Q has its own benefits in reflecting the firm value and the company's potential profitability in the future (Ruan et al., 2011). The reason underlying the use of Tobin's Q as a proxy for firm value is that there is no general agreement regarding a definite measure in measuring firm value, so that Tobin's $Q$ is considered to be used as an alternative proxy for firm value (Mat Nor \& Sulong, 2008). Another reason is that Tobin's Q calculation is simple and has been used widely in various studies on firm value abroad. Tobin's $Q$ is measured by calculating the market value of equity plus the book value of short-term debt and book value of long-term debt divided by total assets (Kumar \& Singh, 2013).

\section{Quality of Governance}

Non-executive directors (independent commissioners) can act as arbiters in disputes between internal managers and oversee management policies and provide advice to management. The higher the proportion of independent commissioners, the tighter the monitoring activities will be. Thus, the agency costs of the company will be smaller so 
that the company will be more efficient which in the end will also be able to increase firm value (Fama \& Jensen, 1983) .

This audit committee is an effort to improve the way the company is managed, especially the way to supervise company management, because it will act as a liaison between company management and the board of commissioners and other external parties. With the audit committee's understanding of the company's internal control system, it is hoped that various acts of fraud and opportunistic management behavior that can harm the company, especially from a financial perspective, can be detected and prevented. In addition, with a monitoring system on the performance of internal auditors by the audit committee, it is hoped that the audit committee will be able to review members of the company's management who are responsible for errors or fraud that can bring financial losses to the company. Thus, it can be concluded that with the existence of an audit committee, it is expected that the company can run effectively and efficiently, so the company value can increase. Previous research result were Obradovich \& Gill (2012); Rouf (2011); Tornyeva \& Wereko (2012) where it is stated that the audit committee variable has a significant positive effect on firm value. Therefore our first hypothesis is :

Hypothesis 1 : The quality of governance affect on firm value

\section{Earnings management}

Scott (2006) defines earnings management as a way of presenting earnings that aims to maximize management utility and / or increase market value through management's selection of a set of accounting procedures policies. Accrual earning management occurs when the company's management uses discretion in the company's financial reporting through various accounting policies to change financial statements, resulting in stakeholders misjudging the company's economic performance or influencing contracts that rely on accounting figures reported in financial statements (Healy \& Wahlen, 1999). The higher the management of the company conducts accrual earning management, the higher the company's performance (Mahdavi-Ardekani et al., 2012). While management opportunistic behavior, as measured by real earnings management, does not affect company performance. (Suryani, et al., 2018). Thus, our second hypothesis is as follows:

Hypothesis 2 : Real earnings management affects firm value

\section{Internal control}

According to Krismiaji ( 2010), internal control is, "Internal control is an organizational plan and methods used to safeguard or protect assets, produce accurate and reliable information, improve efficiency, and encourage compliance with management policies". Meanwhile, according to SA Section 319 Considerations for Internal Control in Financial Statement Audit paragraph 06 in Mulyadi (2002) defines "control is a process that is influenced by the board of commissioners, management, and other business unit personnel, which is designed to obtain adequate assurance about the achievement of objectives in the following matters: Reliability of financial reporting, compliance with applicable laws and regulations, and operating effectiveness and efficiency.

Hypothesis 3 : Quality of governance affects firm value with internal control as a moderating variable

\section{RESEARCH METHODS}

This research method is an explanatory method. The explanatory method is a research method that studies the relationship between two or more variables (Cooper \& Schindler, 
2017). This research method uses a quantitative approach. The type of data used in this study is secondary data. The population in this study are companies listed on the IDX and included in the LQ 45 index from 2016 to 2018. While the sample in this study was taken using purposive sampling method. The samples in this study were non-financial companies that entered consecutively into the LQ 45 Index / blue chip of 27 companies in Indonesia. Further, the empirical analysis model used is Moderating Regression Analysis (MRA) by testing the classical assumptions, testing the hypothesis $\mathrm{F}$ and $\mathrm{t}$ with a significance level of $95 \%$ or $\alpha(5 \%)$, as well as testing the coefficient of determination. The regression equation model is:

$$
\mathrm{Y}=\mathrm{a}+\mathrm{b}_{1} \cdot \mathrm{X}_{1}+\mathrm{b}_{2} \cdot \mathrm{X}_{2}+\mathrm{b}_{3}\left(\mathrm{X}_{1} \cdot \mathrm{X}_{3}\right)+\mathrm{e}
$$

Where: $\mathrm{Y}=$ Firm Value, $\mathrm{a}=$ Constant, $\mathrm{b}_{1} \mathrm{~b}_{2} \mathrm{~b}_{3}=$ Variable $\mathrm{X}$ Coefficient. $\mathrm{X}_{1}=$ Quality of Corporate Governance, $\mathrm{X}_{2}=$ Real earning Management, $\mathrm{X}_{3}=$ Internal Control and $\mathrm{e}=$ error. Table 1 below explains the measurement of the variables, scaling with related references of Quality of Corporate Governance, internal control, earning management and performance.

Table 1: Operational Variables

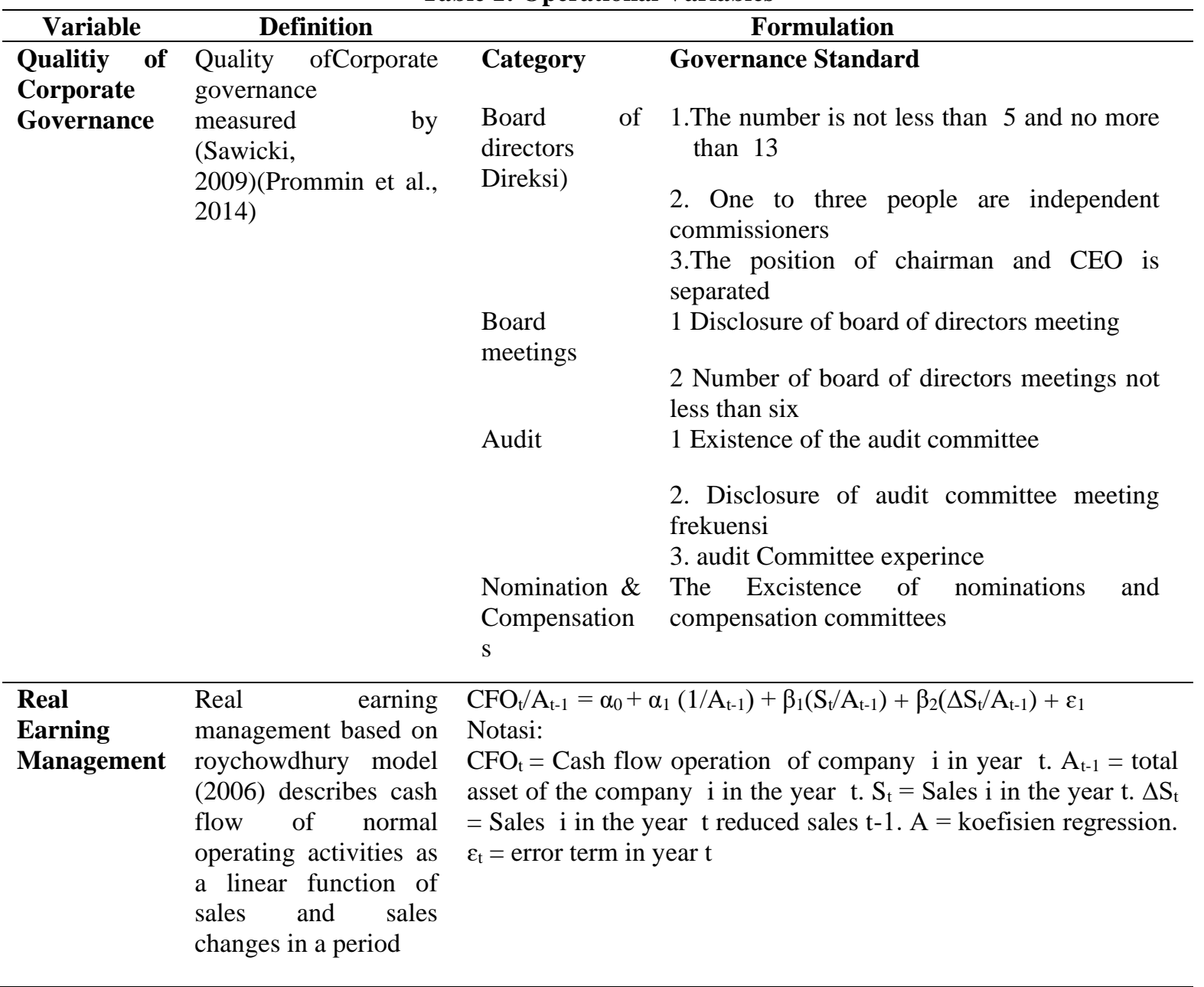




\begin{tabular}{lll}
\hline Internal & Internal control is an & Sistem control system by Deumes \& Knechel ( 2008) developed \\
Control & organizational plan by Hunziker ( 2013 ) : (a) Objective ( b) Responsibility (c) \\
& and method used to Effectiveness (d) Special Element (e) Limitations (f) Monitoring \\
& maintain or protect $(\mathrm{g})$ Internal Audit for internal control \\
& assets, produce & \\
& accurate and reliable \\
information, improve \\
efficiency, and to \\
encourage the \\
adhered management \\
policy" (Hunziker, \\
2013).
\end{tabular}

\section{FINDINGS AND DISCUSSION}

Hypothesis testing in this study is used to test the truth of the hypothesis which states that it is suspected that Corporate Governance, Earning Management have an influence on Firm Value and Internal Control as moderating variables. The results of hypothesis testing in this study were carried out by moderating regression analysis.

The purpose of this test is to determine whether the moderating variable will strengthen or weaken the relationship between the independent and dependent variables. There are three ways to test regression with moderating variables, namely:1) Interaction test, 2) Test the absolute difference value,3) Residual test.Hypothesis testing with moderation regression in this study uses interaction tests. Testing of the pure moderator is done by making interaction regressions, and the moderator variable does not function as an independent variable.All variables can be said to be moderating variables if they have a significant value $<0.05$ (Ghozali, 2013). Following are the results of the interaction test (pure moderator) with internal control as a moderating variable, the influence of Corporate Governance and Earnings Management on Firm Value .

a. Results of Firm Value Testing .

1) Determination Coefficient Test (Adjusted R-Square)

Done to measure the ability of the independent variable to explain the dependent variable. Table 2 . presents the results of the adjusted coefficient of determination (Adjusted R-Square) for this study.

Table 2. Model Summary

\begin{tabular}{lccccc}
\hline Model & $\mathrm{R}$ & R Square & $\begin{array}{c}\text { Adjusted R } \\
\text { Square }\end{array}$ & $\begin{array}{c}\text { Std. Error of the } \\
\text { Estimate }\end{array}$ & Durbin-Watson \\
\hline 1 & $.776^{\mathrm{a}}$ & .603 & .587 & .54557 & 1,749 \\
\hline a. Predictors: (Constant), Real, CG, ModCG \\
\hline
\end{tabular}

In the table above shows that the variable firm value can be explained by the variable Corporate Governance and Earnings Management and the interaction between the independent variables with a moderation of 0,587 or $58,7 \%$. While the remaining 0,413 or $41,3 \%$ explained other factors that were not included in this study. Other factors that can affect firm value include capital structure, profitability, company size and so on.

2) Statistical Test $F$ 
The F statistical test is carried out to test whether the model used is significant. If the significant value $<0.05$, it can be stated that the model used is significant. Table 3 below presents the results of the F statistical test for this study.

Table 3. Statistical Test Results F ANOVA a

\begin{tabular}{llrrrrr}
\hline Model & & $\begin{array}{c}\text { Sum of } \\
\text { Squares }\end{array}$ & D f & \multicolumn{1}{c}{$\begin{array}{c}\text { Mean } \\
\text { Square }\end{array}$} & F & Sig. \\
\hline \multirow{3}{*}{1} & Regression & 34,778 & 3 & 11,593 & 38,947 & $.000^{\mathrm{b}}$ \\
\cline { 2 - 7 } & Residual & 22,919 & 77 & .298 & & \\
\cline { 2 - 8 } & Total & 57,697 & 80 & & & \\
\hline
\end{tabular}

a. Dependent Variable: Tobins

b. Predictors: (Constant), Real, CG, ModCG

Based on table the table above. shows that the significant value in the Sig. equal to 0.000 , which is $<0.05$. So it can be concluded that the research model used in this study is fit.

\section{3) Partial Signification Test (t Statistical Test)}

The $t$ statistical test is carried out to see how far the influence of one independent variable individually explains the dependent variable. If the significance value $<0.05$, it can be stated that the independent variable individually affects the dependent variable (Ghozali, 2013). The following is the result of the partial significance test (t statistical test) which is presented in table below:

\begin{tabular}{|c|c|c|c|c|c|c|}
\hline \multicolumn{7}{|c|}{ Table 4.Coefficients ${ }^{\text {a }}$} \\
\hline \multirow[t]{2}{*}{ Model } & & Unstandardize & Coefficients & Standardized & $\mathrm{t}$ & Sig. \\
\hline & & B & Std. Error & Beta & & \\
\hline \multirow{4}{*}{1} & (Constant) & 1,054 & .239 & & 4,411 & .000 \\
\hline & $\mathrm{CG}$ & -339 & .396 & -.075 & -855 & .395 \\
\hline & Real & 1,258 & .118 & .772 & 10,692 & .000 \\
\hline & ModCG & .056 & .150 & .033 & .373 & .710 \\
\hline a. De & ent Varia & bins & & & & \\
\hline
\end{tabular}

Based on Table above, can be obtained regression model 1 as follows:

$$
\mathrm{Y} 1=1.054-\text { of } 0,339 \mathrm{X}_{1}+1.258 \mathrm{X}_{2}+0.056\left(\mathrm{X}_{1} \mathrm{X}_{3}\right)+0.239
$$

Where:

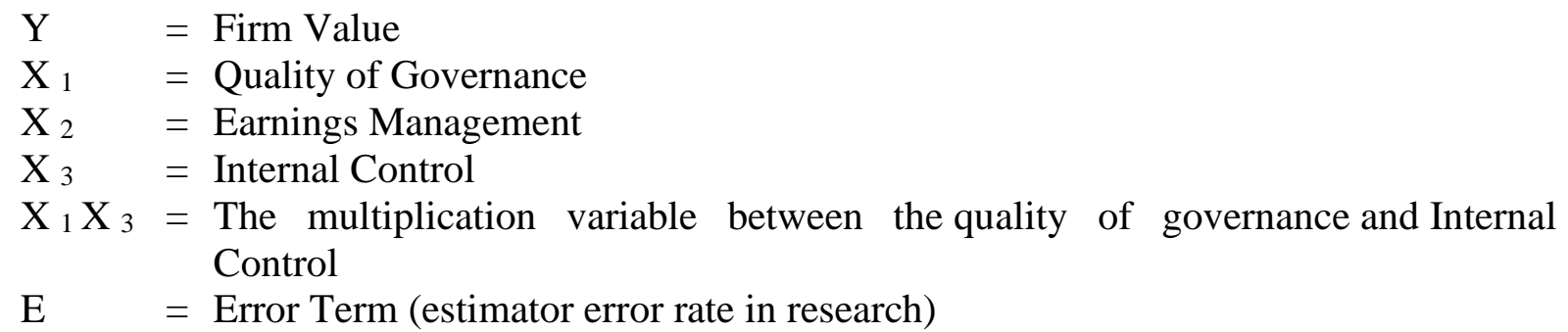

\section{The Effect of the Quality of Governance on Firm Value}

Hypothesis test results are in table coefficient. shows that the level of significance in the variable quality of governance by 0.395 . This means that this study does not support the first hypothesis, because the level of significance of the governance quality variable is $>0.05$. This research is in line with research Sawicki,(2009) where corporate governance scores in Southeast Asia continued to increase for all countries after the crisis, but for companies in Indonesia still ranked last in 2002, Thailand and Singapore 
far exceeded. This is due to economic restructuring and an emphasis on improving their governance more quickly after the crisis.

\section{The Effect of Control Internal as the moderating influence of Quality of Governance on Firm Value}

Results of testing the hypothesis in table coefficient shows that the interaction between the quality of governance by Control Internal had a significance level of 0,710 . This means that this study does not support the second hypothesis (H2) because the significance value above 0,05 sehingga said that there cannot be a moderating variable between the quality of governance and internal control to corporate value.

\section{Effect of Management Earnings towards Firm Values}

Hypothesis test results are in table coefficient. shows that the level of significance of the Real Earning Management variable is 0,000. This means that this study supports the third hypothesis (H3), because the level of significance of the Real Earning Management variable is $<0.05$. Outcome of this study was not consistent with research ( suryani, et al., 2018) shows the behavior management of opportunistic through the management of real profit does not affect the company's financial performance and the results showed that companies listed on stock exchanges Indonesia tend to do accrual earnings management compared to real earnings management.

\section{CONCLUSION AND SUGESTION \\ Conclusion}

Based on the hypothesis, the results of the research and discussion, the following conclusions can be drawn:

1. The Quality of Governance does not have a significant effect on Firm Value in companies indexed by LQ 45 on the Indonesia Stock Exchange. There is no influence of the Quality of Governance on firm value in a negative direction. This means that the increase in the quality of governance does not increase the value of the companies included in the LQ 45 index

2. Earnings management has a significant effect on Firm Value. The effect of earnings management on firm value in a positive direction. This means that the increase in real earning management, the firm value also increase.

3. Internal control cannot moderate the influence of Governance Quality on Firm Value. It does not affect it in a positive direction, which means that internal control cannot strengthen the quality of governance against company value which is included in the LQ 45 index.

\section{Sugestion}

Based on the above conclusions, effective and efficient internal control is highly dependent on the people who carry it out, because the internal control system can provide adequate confidence for management and investors so that the company's goals can be achieved. for future research can add other variables that as moderating variables and add companies including small companies

\section{REFERENCE}

Cooper, Donald R., Boris Bloomberg \& Pamela, 2008. Business Research Method. Second European Edition, USA. Mc Graw Hill International Edition.

Fama, EF, \& Jensen, MC (1983). Agency Problems and Residual Claims. The Journal of Law and Economics , 26 (2), 327-349. https://doi.org/10.1086/467038 
Gill, A., \& Obradovich, J. (2012). The impact of corporate governance and financial leverage on the value of American firms. International Research Journal of Finance and Economics , 91 (February), 46-56.

Hastuti, TD, Ghozali, I., \& Yuyetta, ENA (2017). The Effect Of Company Life Cycles On The Accruals Earning Management With Internal Control System As Moderating Variable. Polish Journal of Management Studies, 15 (1), 6675. https://doi.org/10.17512/pjms.2017.15.1.07

Healy, PM, \& Wahlen, JM (1999). A Review of the Earnings Management Literature and Its. Accounting Horizons , 13 (4), 365-383. https://doi.org/10.2308/acch.1999.13.4.365

Hunziker, S. (2013). Internal Control Disclosure and Agency Costs - Evidence from Switzerland listed non-financial companies. Stefan Hunzikera, 11 (January), 50.

Krismiaji, 2010. Accounting Information Systems . Yokyakarta: UPP AMP YKPN.

Kumar, N., \& Singh, JP (2013). Effect of board size and promoter ownership on firm value: Some empirical findings from India. Corporate Governance (Bingley) , 13 (1), 8898. https://doi.org/10.1108/14720701311302431

Mahdavi-Ardekani, A., Younesi, N., \& Hashemijoo, M. (2012). Acquisition, Earnings Management and Firm's Performance: Evidence from Malaysia. Journal of Business Studies Quarterly , 4 (1), 91-110.

Mat Nor, F., \& Sulong, Z. (2008). Dividends, ownership structure and board governance on firm value: empirical evidence from Malaysian listed firms. Malaysian Accounting Review , 7 (2).

Mulyadi. 2002. Accounting information system. Jakarta: Publisher Salemba Empat

BAPEPAM Regulation No KEP - 339 / BEJ / 07 - 2001

Prommin, P., Jumreornvong, S., \& Jiraporn, P. (2014). The effect of corporate governance on stock liquidity: The case of Thailand. International Review of Economics and Finance , 32 , 132-142. https://doi.org/10.1016/j.iref.2014.01.011

Roychowdhury, S. (2006). Earnings management through real activities manipulation. Journal of Accounting and Economics, 42 (3), 335370. https://doi.org/10.1016/j.jacceco.2006.01.002

Ruan, W., Tian, G., \& Shiguang, M. (2011). Managerial Ownership, Capital Structure and Firm Value: Evidence from China's Civilian-run Firms. Australasian Accounting Business and Finance Journal , 5 (3), 73-92.

Sawicki, J. (2009). Corporate governance and dividend policy in Southeast Asia pre- and post-crisis. European Journal of Finance, 15 (2), 211230. https://doi.org/10.1080/13518470802604440

Suryani, A., Pirzada, K., \& Mufidah. (2018). Analysis of opportunistic behavior of management to company performance. Polish Journal of Management Studies , 18 (1), 379-388. https://doi.org/10.17512/pjms.2018.18.1.28

Scott, William, R. 2006. Financial Accounting Theory. Fifth Edition. Canada Prentice Hall 